to China, where perhaps it finds its prototype in the flake implements of Peking man. This, to his mind, suggests a dual origin for the races of early palæo. lithic Europe, one branch coming from Africa where the coup de poing occurs with some frequency, and the second bringing the flake industry from Asia. He applies the same argument to Aurignacian man, pointing out that while the female statuette of upper palæolithic date has never been found in Africa, it occurs in Russia and examples have recently been found so far east as Maltá in Siberia. As the African affinities of Aurignacian man, or rather of his culture are not to be questioned, Europe would again in this period represent the point of confluence of two streams of migration.

\section{Prof. A. Stoll's Researches in Biochemistry}

THE biochemists in Germany publish their results in the Biochemische Zeitschrift, and some ten thousand original papers have been published in it in the past twenty-six years. The American and British work has been even more fruitful, at least in quality, during this period, so that there is little wonder that we are beginning to make progress in unravelling both the nature and structure of the substances found in the living cell and in understanding something of the reactions which take place there. Prof. Arthur Stoll of Basel has recently put together, for the purpose of a lecture, his own experiences since 1909 in developing some sections of biochemistry ("Ein Gang durch biochemische Forschungsarbeiten", pp. $41+5$ plates. Berlin : Julius Springer, 1933. 3 gold marks), much as in another walk of life a traveller might do on his return from a lengthy journey. Stoll began research with Willstätter and the chlorophyll molecule, and he returns to it at the end of his journey, for it has not yet given up all its secrets. In the meantime he has concerned himself with ergot, with scillarin, and with the digitalis glycosides. His pamphlet, which is illustrated, makes attractive reading: we concern ourselves too much nowadays with the abstruse intricacies of our sciences, and would be well advised to view them occasionally from a wider angle.

\section{Reopening Limestone Oil Wells with Acid}

THE natural flow of an oil well may recede either from the exhaustion of the oil supply or as the result of a stoppage of the pores of the oil-bearing rock cutting off the free supply of oil. In the past, somewhat drastic methods have been tried to overcome this drawback, but they are difficult to carry out, especially at a depth which may be half a mile below the surface. When the well is in a limestone formation, it has now been discovered that it is possible to open it up again by treatment with successive quantities of 10 or 15 per cent hydrochloric acid, which dissolve new channels in the calcareous rock and permit of a new flow of oil. The use of hydrochloric acid is only made possible by the addition to it of 1-5 per cent of an arsenic compound, which inhibits the action of the acid on the metallic casing and pump tubes of the well. Other inhibitors, including certain organic nitrogen bases, have been discovered but the arsenic compounds are the most convenient to apply in practice. The discovery has been made by the Dow Chemical Co. in partnership with the Pure Oil Co., and patented as the Dowell process : it is described in greater detail in the News Edition of Industrial and Engineering Chemistry for February 20. The use of acid made inactive towards metal surfaces is a novel and important one : it may be a revolutionary factor in oil production. Further, it is likely to be beneficial in natural gas production and in other directions. It is certainly an achievement to be able to control the action of a strong acid as a boring agent half a mile below the surface.

\section{Petroleum Production in Russia}

According to Science Service of Washington, D.C., the petroleum production of Soviet Russia has now attained the position of being the second largest in the world, the estimated yield last year being 150 million barrels. Many factors have conduced to this remarkable advance, but chiefly the confiscation of oil property and its operation under Government directorship without competition have been responsible. The fields have the additional advantage that they are well situated for transport of oil to foreign markets and they are also easy to develop and operate. Another factor in the situation is the rosults. of exploratory work, which have indicated the existence of potential oilfields along a tract of country stretching from the Arctic Ocean to the Caspian Sea. From the point of view of economics, as emphasised by Mr. R. C. Beckstrom to the American Institute of Mining and Metallurgical Engineers recently, Russia's home consumption is based mainly on industrial development and particularly on the extensive use of tractors for agxicultural purposes, while external markets for oil lie chiefly with Italy, France and England, to which more than forty million barrels were exported last year. If the ambitious goal of more than 480 million barrels of oil production for 1937 is realised by the Soviet authorities, then clearly the whole scheme of international stability, in so far as petroleum supplies are concerned, will receive a severe shock.

\section{Institution of Heating and Ventilating Engineers}

THE Institution of Heating and Ventilating Engineers of 12, Russell Square, W.C.l, now issues a Journal, the first number of which was published in March. The object of the Journal is to keep its members in touch with the latest practice both at home and abroad and in particular to give them the latest results of the research work being done on the subject. In the first issue, an important paper by $\mathrm{E}$. Herring is published giving the methods that have been employed for warming and ventilating the Masonic Peace Memorial building in Great Queen Street, London, W.C.2. As many masonic meetings will be held there, it was necessary to use special precautions so as to eliminate the possibility of sound being transmitted from one room to another. All the fans, motors, and machinery had to run silently and it was necessary that the rate of ventilation and 